\title{
UGI Endoscopy Findings In Patients Admitted With Non Variceal UGI Bleed and Assessing The Outcome
}

\author{
Dr. K.Sivakumar MD ${ }^{1}$, Dr.G.Gowthami MD², Dr.P.Praveen Kumar ${ }^{3}$ \\ ${ }^{I}$ Senior Assistant Professor, Department of General Medicine, Coimbatore medical college hospital, \\ Coimbatore, Tamilnadu, India. \\ ${ }^{2}$ Assistant Professor, Chengalpattu Medical College Hospital, Chengalpattu, Tamilnadu. \\ ${ }^{3}$ Postgraduate in General Medicine, Department of General Medicine, Coimbatore medical college hospital, \\ Coimbatore, TamilNadu.
}

\begin{abstract}
Objectives: To describe the etiology, association factors, co morbid conditions and the most common endoscopic findings associated with Non-variceal Upper Gastro Intestinal Bleeding (UGIB).

Methods And Materials: The study was conducted at Coimbatore medical college hospital during the period of January 2016 to May 2016.It is a Retrospective study.The study population included 100 patients who are presented with hemetemesis or melena and admitted in medical ward during that period.

Statistical Analysis: The collected data was analysed with SPSS 16.0 version. To describe about the data descriptive statistics frequency analysis,percentage analysis, mean, S.D were used.To find the significance difference between for the Independent samples and for multiple comparison one way ANOVA with Tukey's Post Hoc test was used. In both the above statistical tools the probability value P value 0.05 is considered as significant level.

Results: Upper gastro intestinal bleed is more common in males than females and affect males predominantly in the age group of 20 to 60 years. NSAID intake and alcohol intake are a well known risk factors for UGIB. Ischemic heart disease is most common comorbid condition in UGIB and it increases the duration of hospital stay. It denotes aspirin is directly associated with UGIB. Gastric inflammation (Erosive mucosal disease) is the most common endoscopic finding in our hospital.

Conclusion: Outcome was compared with Rockall Score, it showed positive correlation.Rockall Scoring System is the most useful and effective system in triaging the patients.
\end{abstract}

Keywords: UGI endoscopy, Non-variceal UGI Bleeding

\section{Introduction}

Upper gastrointestinal (UGI) bleeding is a common medical condition than lower gastro intestinal bleeding those results in high morbidity, mortality and medical care costs. The incidence is more common with males than females, and increasing with age ${ }^{5}$. Patients with upper GI bleeding, clinical symptoms varies from hematemesis, malena, syncope or asymptomatic iron-deficiency anemia. Sometimes hematochezia may be due to bleeding from an upper GI source ${ }^{4}$. Those who present with massive bleeding or hypotension require treatment in an intensive care unit. They need early and urgent endoscopic evaluation to identify the risk.The patient with low risk of re bleeding without hypotension and no significant co-morbid conditions can be discharged earlier. To assess the risk group, it needs endoscopic evaluation and scoring system. Many scoring systems are available to assess the risk. Rockall scoring system is the most useful and externally validated scoring system in many countries. In this study identifying the risk group by post endoscopic rockall scoring system, we triage the patient into high or low risk. We hope that this study could provide the baseline data from which future guidelines use rockall scoring system to assess the risk groups.

\section{Methodology}

Collection of data regarding personal history including smoking habits, alcohol intake, past history of similar complaints, medical history like HT, DM, Drug intake, peptic ulcer history was done. Endoscopy was done for all our study patients. Risk for re bleeding and death was analyzed with post endoscopy Rockall scoring system. Rockall score was taken for risk analysis and triaging the patient into high risk or low risk. Measures of adverse outcome and healthcare resource utilization was done by assessing the duration of hospital stay, re bleeding, requirement of blood transfusion and I.V fluids and mortality rate.

Statistics: The collected data was analysed with SPSS 16.0 version. To describe about the data descriptive statistics frequency analysis, percentage analysis, mean, S.D were used. To find the significance difference between for the Independent samples and for multiple comparison one way ANOVA with Tukey's Post Hoc test 
was used. In both the above statistical tools the probability value $\mathrm{P}$ value 0.05 is considered as significant level. Comparison between two categories were made, using student t-test for continuous variables. To analyze categorical data, chi square test is performed. Analyzed data was preserved in the form of tables and graphs.

\section{Results}

During the study period, a total of 100 patients were included in the study, of age ranging from 16 years to 85 years. The mean age of patients with UGIB included in our study was 50.5 years (range $=16$ to 85 years). The most common age group affected in our study population was 41 to 60 years (44 patients or $44 \%$ ),followed by age group of 21 to 40 years (35 patients or 35\%). There was only 15 patients above the age of 60 years constituting $15 \%$ of the total number of patients.

Chart 1-Age wise distribution of study population Table 2-Age group wise distribution of male and female patients

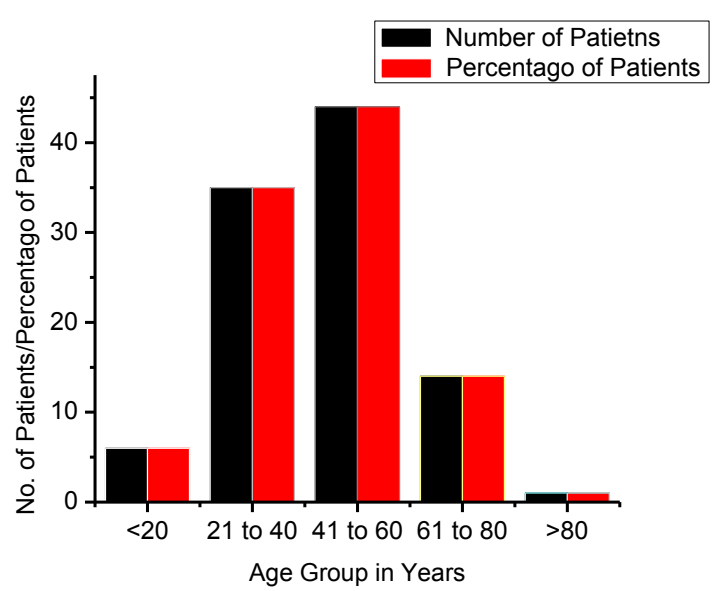

Percentage of Alcoholics in UGIB

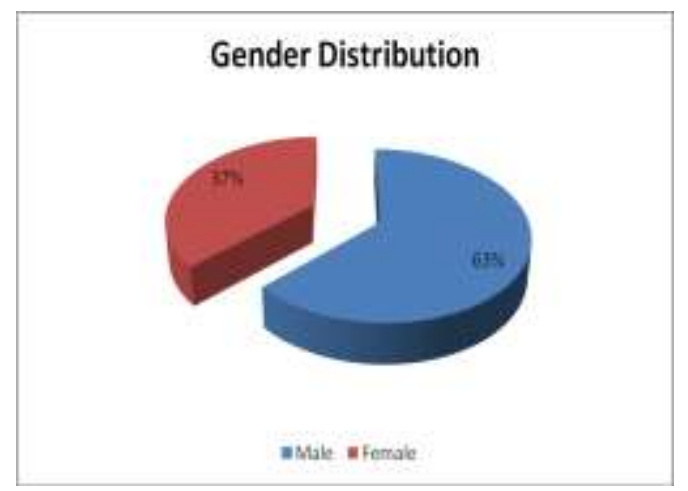

Percentage Rebleeding in UGIB

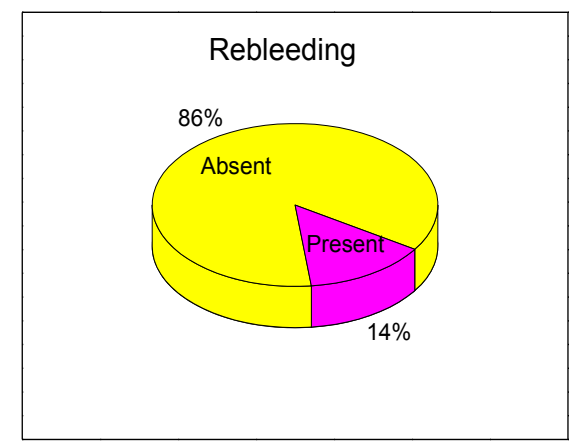

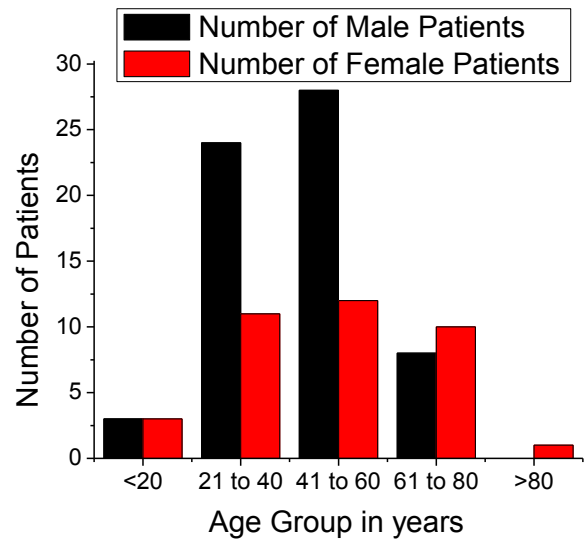

Gender frequency

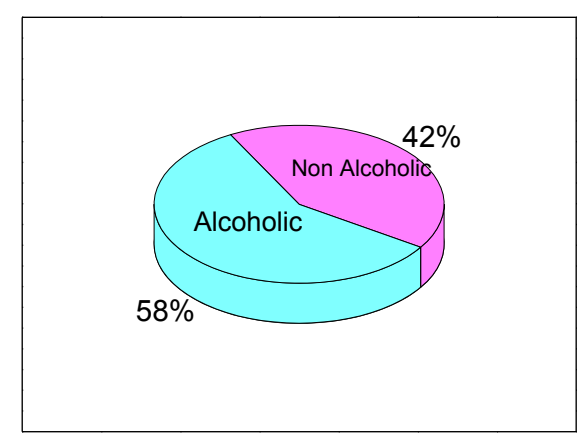

Percenage of Drug intakers

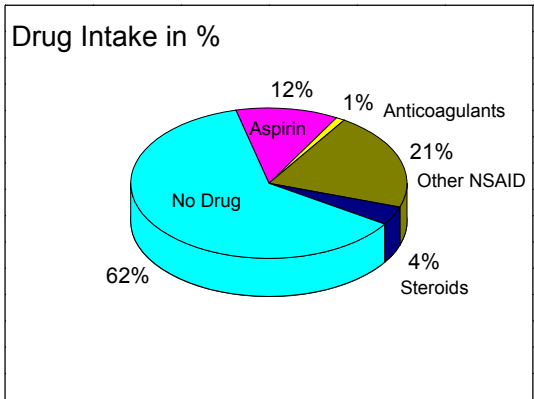




\section{Frequencies of co- morbid conditions in UGIB}

Among the study population $17 \%$ of the patients were associated with ischemic heart disease or congestive cardiac failure.Liver cell failure accounts for $1 \%, 3 \%$ patients are associated with renal failure,5\% patients are associated with malignancy.Eight percent of the patients were associated with other disorders like COPD,Systemic sclerosis and etc.., There is no associated disorders in $66 \%$ of the patients.

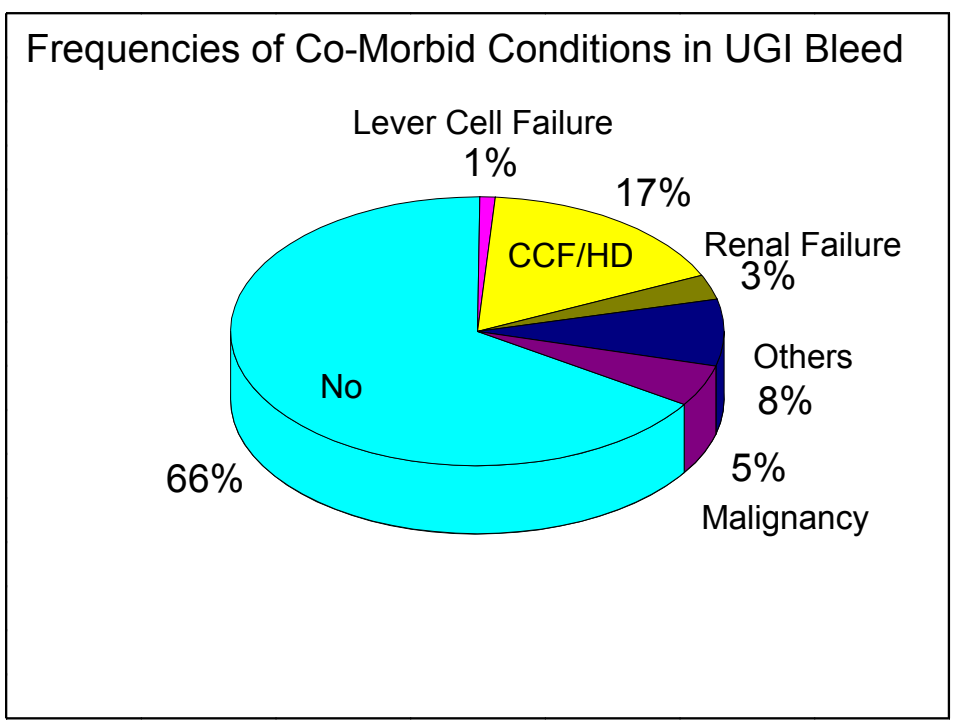

\section{Endoscopy findings}

In our study ,among 100 subjects ,the most common endoscopic finding is Gastric inflammation. It is followed by Esophageal mucosal tear(Mallory weiss tear) ,Gastric ulcer ,duodenal ulcer and duodenal inflammation,Malignancy ,congenital anomalies like Hiatus hernia,diverticulosis in the decending order. Duodenal ulcer was less common finding than gastric ulcer.Malignancy was found in $5 \%$ of the subjects.Combined lesions are more common than the single lesion. Gastic ulcer and duodenal ulcer both combined lesion found in $1 \%$ of the subjects.

Table 6 - Endoscopy Findings

\begin{tabular}{|l|l|l|}
\hline Sl.no & Endoscopy findings & \% of Patients \\
\hline 1 & Esophageal Mucosal inflammation & 10.0 \\
\hline 2 & Gastric inflammation & 16.0 \\
\hline 3 & Duodenal Inflammation & 1.0 \\
\hline 4 & Gastric ulcer & 15.0 \\
\hline 5 & Duodenal ulcer & 1.0 \\
\hline 6 & Growth & 5.0 \\
\hline 7 & Gastric inflammation and Duodenal Inflammation & 6.0 \\
\hline 8 & Gastric Inflammation, Anamolies - Hiatus Hernia, Divertic & 3.0 \\
\hline 9 & Esophageal Mucosal tear, Gastric inflammation, Anamolies & 5.0 \\
\hline 10 & Gastric inflammation, Gastric ulcer & 7.0 \\
\hline 11 & Gastric ulcer, Duodenal ulcer & 1.0 \\
\hline 12 & Esophageal Mucosal tear, Gastric inflammation, Anamolies & 2.0 \\
\hline 13 & Esophageal Mucosal tear, Gastric inflammation & 10.0 \\
\hline 14 & Esophageal Mucosal tear, Duodenal inflammation & 2.0 \\
\hline 15 & Esophageal Mucosal tear, Gastric inflammation & 4.0 \\
\hline 16 & Esophageal Mucosal tear, Gastric inflammation, Duodenal inflammation & 4.0 \\
\hline 17 & Esophageal Mucosal tear, Duodenal inflammation, Gastric ulcer & 1.0 \\
\hline 18 & Duodenal inflammation and Gastric ulcer & 2.0 \\
\hline 19 & Esophageal Mucosal tear, Duodenal ulcer, Gastric ulcer & 2.0 \\
\hline 20 & Esophageal Mucosal tear(Mallory weiss syndrome) & 2.0 \\
\hline 21 & Esophageal Mucosal tear, Gastric ulcer & 2.0 \\
\hline 22 & Esophageal Mucosal tear, Gastric inflammation, Duodenal ulcer & 3.0 \\
\hline 23 & Esophageal Mucosal tear, Gastric inflammation and Gastric ulcer & 4.0 \\
\hline
\end{tabular}




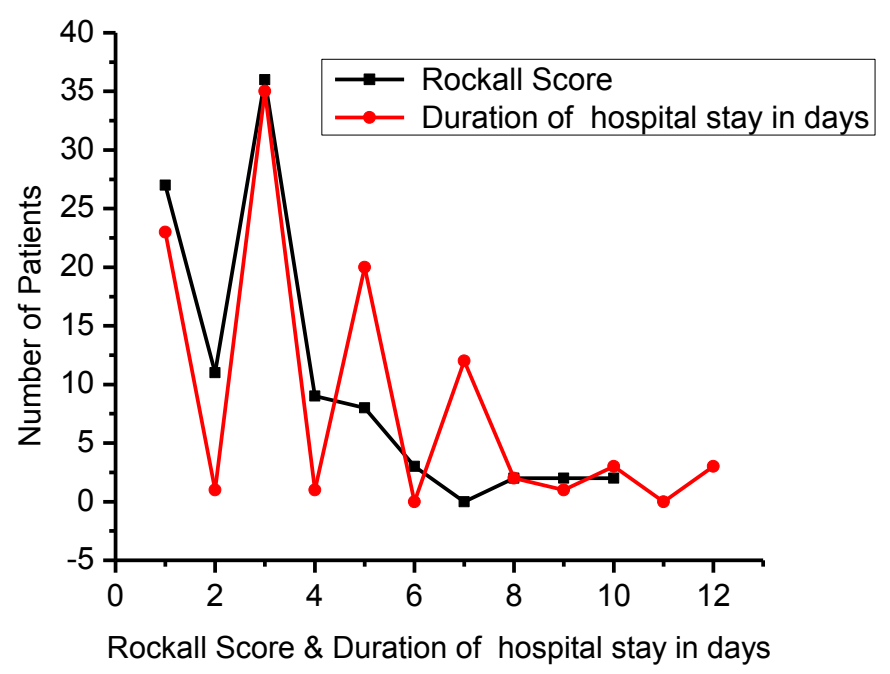

Duration of hospital stay correlates with Rockall score, it has proved statistically. The Rockall score ranged from 1-10 with a mean $( \pm \mathrm{SD})$ of $3.8( \pm 1.6)$. Increased Rockall score was significantly associated with increased need of blood transfusion $(\mathrm{P}=0.016)$, length of hospital stay $(\mathrm{P}=0.011)$ and mortality $(\mathrm{P}=0.000)$.Rockall score is useful indicator to predict the mortality.Post endoscopic rockall score is accurate and externally validated in many countries.In our study ,shows increase in the score is associated with high mortality.

\section{Discussion}

There is very little Indian literature on endoscopic findings in UGI bleed and outcome assessment using Rockall Score. This study was done in Karnataka as Upper Gastro Intestinal Bleed and Rockall Score, authors have concluded that Rockall Score is a useful scoring system in triaging the patients and predicting the outcome. In our study, patients are in the age group from 16 years to 85 years. The mean age of patients in our study was 50.5 years, little lower compared to western studies $46,10,48,50$. This could be a reflection of the presence of higher older population in the west. Male patients constituted the large proportion in the age group of 20 to 60 years. Female patients were more above the age of 60 years. Overall the male patients are more in number than female patients as in western studies $45,10,48,49$. Risk of NSAIDs The use of NSAID is a well known risk factor associated with UGI Bleed51, 52. This is confirmed in our study which shows $21 \%$ of the patients are NSAID intakers with UGIB. It was higher compared to other drugs. NSAID is an easily available drug taken by the patient and commonly causes erosive medical disease and peptic ulcer. This was proved in our study. Regulations to discourage the dispensing of NSAID without prescription of a qualified medical practitioner is of paramount importance in reducing the above complications. Alcohol consumption has increased nowadays and it is a well known risk factor for UGI Bleeding52. In our study 58\% of the patients were alcoholic. Number of alcoholic patients were higher than non alcoholics in our study. We could not find any significant association between abuse of alcohol and specific endoscopic lesions or with a higher mortality rate.Smoking is a well known associated factor with peptic ulcer.In our study, it accounts for $54 \%$ and is more associated with gastric ulcer. Common associated medical condition are hypertension and diabetes mellitus. Nowadays these are increasing due to the high prevalence of HT and DM in the general population. In our study, the comorbid conditions most commonly associated were cardiac failure, malignancy and renal failure. Re bleeding rates reported in michigan study is around $20-30 \%$ of patients and is associated with a high risk of death 57 . In our study, re bleeding was noted in $14 \%$, a figure which is significantly low compared to that found in previous studies 48 , 57. Early identification and aggressive treatment reduces the rebleeding. Blood pressure was low in $46 \%$ of our patients. Hemoglobin level less than $8 \mathrm{gms}$ accounts for $13 \%$ of patients and it indicates the requirement of blood transfusion. Platelet count was low (less than 1.5 lakhs), in $11 \%$ of the patients could be due to drug induced or concurrent infection.

Our study showed that gastric inflammation(Erosive mucosal disease) is the most common endoscopic finding, contradictory to other studies in which peptic ulcer was more common after varices7, 47, 49. Peptic ulcer is more common than variceal bleeding in western countries. 10,33,48. Gastric ulcer is commoner than duodenal ulcer. Peptic ulcer is more commonly due to H.Pylori infection. We could not find out the prevalence of H.Pylori,in which urea breadth test and tissue biopsy is not routinely done in all patients. In agreement with other studies,the majority of the patients in this study were treated medically $47,48,55$. About $69 \%$ of the 
patients were given blood transfusion. All patients are treated with I.V. fluids and I.V. PPI. Proton pump inhibitors reduce the chances of rebleeding. The overall duration of hospital stay in our study was the same, as

study done by hyasinta in tanzania reported in previous studies 59. High score in the Rockall scoring system was associated with increase in the duration of hospital stay. The overall mortality rate in our study was $10 \%$ which is equal to the studies reported in most western countries 23,58 . The high mortality rate in our study could be due to associated underlying medical conditions, comorbidities and in patients with hypotension, age $>60 y e a r s$, higher Rockall Score.Our study showed that increase in the Rockall Score was associated with increased requirement of blood transfusion,increased chance of rebleeding, increase in the duration of hospital stay and high mortality.

\section{Conclusion}

Gastric inflammation(Erosive mucosal disease) is the most common endoscopic finding in our hospital. Rockall scoring system is the most useful and effective system in triaging the patients.

\section{Bibliography}

[1]. David Edelberg. Digestive Health. Available from http:// www. netplaces. com/ digestive- health.

[2]. Simic O, Strathausen S, Hess W, Ostermeyer J. Incidence andprognosis of abdominal complications after cardiopulmonary bypass. Cardiovasc Surg 1999; 7(4): 419-24.

[3]. Mayer EA. The challenge of studying the biology of complex, symptom-based GI disordears. Gastroenterology 2000; 133(4): 111323.

[4]. Drossman DA. The functional gastrointestinal disorders and the Rome III process. Gastroenterology 2006; 130(5): 1377-90.

[5]. Longstreth GF. Epidemiology of hospitalization for acute upper gastrointestinal hemorrhage: a population-based study. Am J Gastroenterol 1995; 90:206. Available from http://www.uptodate.com/contents/major-causes-of-upper-gastrointestinal-bleeding-inadults.

[6]. Margaret Shuhart,. Kris Kowdley, and Bill Neighbor,. Gastrointestinal Bleeding. Available from http://www.uwgi.org/ guidelines/ch_07/ ch07txt.htm

[7]. Kibiki GS, Hauser M, Lyamuya S, Lyaruu I, Ole-Nguyaine S, Dolmans W: Causes of upper gastrointestinal bleeding in Tanzania. Tanzania Medical Journal 2003, 18:28. OpenURL.

[8]. $\quad$ R D Yajko, L W Norton, and B Eiseman. Current management of upper gastrointestinal bleeding. Ann Surg. 1975 April; 181(4): 474-480.Available from http://www.ncbi.nlm.nih.gov/pmc/articles/PMC1343792/

[9]. Fallah MA, Prakash C, Edmundowicz S. Acute gastrointestinal bleeding. Med Clin North Am. Sep 2000;84(5):1183-208.

[10]. Rockall TA, Logan RF, Devlin HB, Northfield TC: Incidence of and mortality from acute upper gastrointestinal haemorrhage in the united kingdom. steering committee and members of the national audit of acute upper gastrointestinal haemorrhage. BMJ 1995, 311:222-226. PubMed Abstract | Publisher Full Text | PubMed Central Full Text OpenURL

[11]. Almeida D, Lopes AA, Santos-Jesus R, Paes I, Bittencourt H, Paraná R. Comparative study of bacterial infection prevalence between cirrhotic patients with and without upper gastrointestinal bleeding. Braz J Infect Dis. 2001 Jun;5(3):136-42. Available from http://www.ncbi.nlm.nih.gov/pubmed/11506777.

[12]. Sarin N, Monga N, Adams PC: Time to endoscopy and outcomes in upper gastrointestinal bleeding. Can J Gastroenterol 2009, 23(7):489-493. PubMed Abstract | Publisher Full Text | PubMed Central Full Text OpenURL

[13]. Elghuel A: The characteristics of adults with upper gastrointestinal bleeding admitted to tripoli medical center: a retrospective caseseries analysis.Libyan J Med 2011, 6:6283. OpenURL

[14]. Palmer K: Management of haematemesis and melaena.Postgrad Med J 2004, 80:399-404. PubMed Abstract | Publisher Full Text | PubMed Central Full Text OpenURL

[15]. Rockall TA, Logan RFA, Devlin HB, Northfield TC: Selection of patients for early discharge or outpatient care after acute upper gastrointestinal haemorrhage.Lancet 1996, 347:1138-40. PubMed Abstract | Publisher Full Text OpenURL

[16]. Kivkin K, Lyakhovetskiy A: Treatment of non variceal upper gastrointestinal bleeding.Am J Health-Syst Pharm 2005, 62:11591170. PubMed Abstract | Publisher Full Text OpenURL

[17]. Wolfsen HC, Hemminger L, Achem SR, Loeb DS, Stark ME, Bouras EP, Devault KR: Complications of endoscopy of the upper gastrointestinal tract: a single-center experience. Mayo Clin Proc. 2004, 79(10):1264-1267. PubMed Abstract | Publisher Full Text OpenURL.

[18]. Blatchford O,Davidson LA,Murray WR, Blatchford M, Pell J. Acute Upper gastrointestinal haemorrhage in west of Scotland: Case ascertainment study. BMJ. 19. van Leerdam ME. Epidemiology Of acute upper gastrointestinal bleeding. Best Practice

[19]. Arora NK, Ganguly S, Mathur P, Ahuja A, Patwari A: Upper gastrointestinal bleeding: etiology and management.

[20]. Indian J Pediatr. 2002, 69(2):155-68. PubMed Abstract | Publisher Full Text OpenURL

[21]. Southern DHB. Upper Gastrointestinal Bleeding Guidelines. Dunedin, 2007.

[22]. Leontiadis GI, Sharma VK, Howden CW. Proton Pump inhibitor therapy for peptic Lakhwani MN, Ismail AR, Barras CD, Tan WJ: Upper gastrointestinal bleeding in kuala lumpur hospital, malaysia. Med J Malaysia 2000, 55(4):498-505. PubMed Abstract OpenURL

[23]. Theocharis G, Thomopoulos K, Sakellaropoulos G, Katsakoulis E, Nikolopoulo V: Changing trends in the epidemiology and clinical outcome of acute upper gastrointestinal bleeding in a defined geographical area in greece. J Clin Gastroenterol 2008, 42:128-33. PubMed Abstract | Publisher Full Text OpenURL

[24]. Chasawat J, Prachayakul V, Pongprasobchai S: Upper gastrointestinal bleeding score for differentiating variceal and nonvariceal upper gastrointestinal bleeding. Thai J Gastroenterol 2007, 8(2):44-50. OpenURL.

[25]. Kibiki GS, Hauser M, Lyamuya S, Lyaruu I, Ole-Nguyaine S, Dolmans W: Causes of upper gastrointestinal bleeding in Tanzania.Tanzania Medical Journal 2003, 18:28. OpenURL

[26]. Rockall TA, Logan RFA, Devlin HB, Northfield TC: Selection of patients for early discharge or outpatient care after acute upper gastrointestinal haemorrhage. Lancet 1996, 347:1138-40. PubMed Abstract | Publisher Full Text OpenURL

[27]. Van Leerdam ME, Vreeburg EM, Rauws EAJ, Geraedts AAM, Tijssen JGP, Reitsma JB, Tytgat GNJ: Acute upper Gi bleeding: did anything change? Time trend analysis of incidence and outcome of acute upper Gi bleeding between 1993/1994 and 2000.

[28]. Am. J. Gastroenterol 2003, 98:1494-1499. PubMed Abstract | Publisher Full Text OpenURL 
[29]. Balderas V, Bhore R, Lara LF, et al. The hematocrit level in upper gastrointestinal hemorrhage: safety of endoscopy and outcomes. Am J Med 2011; 124:970.

[30]. Das A, Wong RC. Prediction of outcome of acute GI hemorrhage: a review of risk scores and predictive models. Gastrointest Endosc 2004; 60:85.

[31]. Rockall TA, Logan RF, Devlin HB, Northfield TC. Risk assessment after acute upper gastrointestinal haemorrhage. Gut. 1996;38:316-321.[PubMed]

[32]. Camellini L, Merighi A, Pagnini C, Azzolini F, Guazzetti S, Scarcelli A, Manenti F, Rigo GP. Comparison of three different risk scoring systems in non-variceal upper gastrointestinal bleeding. Dig Liver Dis. 2004;36:271-277.[PubMed]

[33]. Vreeburg EM, Terwee CB, Snel P, Rauws EA, Bartelsman JF, Meulen JH, Tytgat GN. Validation of the Rockall risk scoring system in upper gastrointestinal bleeding. Gut. 1999;44:331-335.[PubMed]

[34]. .Enns RA, Gagnon YM, Barkun AN, Armstrong D, Gregor JC, Fedorak RN. Validation of the Rockall scoring system for outcomes from non-variceal upper gastrointestinal bleeding in a Canadian setting. World J Gastroenterol. 2006;12:7779-7785.[PubMed]

[35]. Church NI, Dallal HJ, Masson J, Mowat NA, Johnston DA, Radin E, Turner M, Fullarton G, Prescott RJ, Palmer KR. Validity of the Rockall scoring system after endoscopic therapy for bleeding peptic ulcer: a prospective cohort study. Gastrointest Endosc. 2006;63:606-612.[PubMed]

[36]. Marmo R, Koch M, Cipolletta L, Capurso L, Grossi E, Cestari R, Bianco MA, Pandolfo N, Dezi A, Casetti T. Predicting mortality in non-variceal upper gastrointestinal bleeders: validation of the Italian PNED Score and Prospective Comparison with the Rockall Score. Am J Gastroenterol. 2010;105:1284-1291.[PubMed]

[37]. Rockall TA, Logan RF, Devlin HB, Northfield TC. Risk assessment after acute upper gastrointestinal haemorrhage. Gut. 1996;38:316-321.[PubMed]

[38]. Rockall TA, Logan RF, Devlin HB, Northfield TC. Selection of patients for early discharge or outpatient care after acute upper gastrointestinal haemorrhage. National Audit of Acute Upper Gastrointestinal Haemorrhage. Lancet. 1996;347:11381140.[PubMed]

[39]. Network SIG. Management Of acute upper and lower gastrointestinal bleeding. Edinburgh2008. Available from: http://www.sign.ac.uk/pdf/sign105.pdf. Accessed On 04 Jan2012.

[40]. Barkun AN, Bardou M, Kuipers EJ, Sung J, Hunt RH, Martel M, Et al. International Consensus recommendations on the management of patients with nonvariceal upper

[41]. Haubrich,schaffner,Berk ."Endoscopy in gastro enterology".2010; Volume 1:299-300.

[42]. Bozzini (1806) "Lichtleiter, eine Erfindung zur Anschauung innerer Teile und Krankheiten, nebst der Abbildung" (Light conductor, an invention for examining internal parts and diseases, together with illustrations), Journal der practischen Arzneykunde und Wundarzneykunst (Journal of Practical Medicine and Surgery), 24 : 107-124.

[43]. Jump up ^ Edmonson, J. M. (1991). "History of the instruments for gastrointestinal endoscopy". Gastrointestinal endoscopy 37 (2 Suppl): S27-S56. doi:10.1016/S0016-5107(91)70910-3. PMID 2044933

[44]. Van Leerdam ME, Vreeburg EM, Rauws EAJ, Geraedts AAM, Tijssen JGP, Reitsma JB, Tytgat GNJ: Acute upper Gi bleeding: did anything change? Time trend analysis of incidence and outcome of acute upper Gi bleeding between 1993/1994 and 2000.

[45]. Am. J. Gastroenterol 2003, 98:1494-1499. PubMed Abstract | Publisher Full Text OpenURL Meaden C, Makin AJ: Diagnosis and treatment of patients with gastrointestinal bleeding.Curr Anaesthesia Crit Care 2004, 15:123-32. Publisher Full Text OpenURL

[46]. Theocharis G, Thomopoulos K, Sakellaropoulos G, Katsakoulis E, Nikolopoulo V: Changing trends in the epidemiology and clinical outcome of acute upper gastrointestinal bleeding in a defined geographical area in greece. J Clin Gastroenterol 2008, 42:128-33. PubMed Abstract | Publisher Full Text OpenURL

[47]. Suba M, Mekonnen SA, Mtabho CM, Kibiki GS: The aetiology, management and clinical outcome of upper gastrointestinal bleeding among patients admitted at the Kilimanjaro Christian Medical Centre in Moshi, Tanzania. Tanzania J. Health Res. 2010, 12(4):286-289. OpenURL

[48]. Zaltman C, Souza HS, Castro ME, Sobral MF, Dias PC, Lemos V: Upper gastrointestinal bleeding in a Brazilian hospital: a retrospective study of endoscopic records. Arquivos de Gastroenterologia 2002, 39:74-80. PubMed Abstract | Publisher Full Text OpenURL

[49]. Mustapha S, Ajayi N, Shehu A: Aetiology of upper gastrointestinal bleeding in north-eastern nigeria: a retrospective endoscopic study. The Internet Journal of Third World Medicine 2009, 8:2. OpenURL

[50]. Kaviani MJ, Pirastehfar M, Azari A, Saberifiroozi M: Etiology and outcome of patients with upper gastrointestinal bleeding: a study from south of Iran. Saudi. J Gastroenterol 2010, 16:253-9. PubMed Abstract | Publisher Full Text | PubMed Central Full Text OpenURL

[51]. Olokoba AB, Olokoba LB, Jimoh AA: Upper gastrointestinal tract bleeding in Ilorin, Nigeria-a report of 30 cases. Niger J Clin Pract. 2009, 12(3):240-4. PubMed Abstract 